\title{
Acute toxicity and ethological responses of oligochaete worm Tubifex tubifex (Muller) exposed to a cationic surfactant Cetylpyridinium chloride
}

\author{
Ritwick Bhattacharya $^{1}$, Arnab Chatterjee ${ }^{2}$, Nimai Chandra Saha ${ }^{3 *}$ \\ ${ }^{1,2,3}$ Fishery and Ecotoxicology Research Laboratory (Vice-Chancellor's Research Group), Department of Zoology, \\ The University of Burdwan, Burdwan, 713104, West Bengal, India \\ *Corresponding author: research.ncsaha@gmail.com
}

Available online at: www.isroset.org

Received: 12/Apr/2019, Accepted: 25/Apr/2019, Online: 30/Apr/2019

\begin{abstract}
Cetylpyridinium chloride is a quaternary cationic surfactant which exhibit broad spectrum antimicrobial activity. The present study was conducted to evaluate the acute toxicity of Cetylpyridinium chloride to a benthic oligochaete worm Tubifex tubifex in terms of $\mathrm{LC}_{50}$ and behavioral responses. All experiments were conducted, in a static bioassay system, using increasing concentrations of Cetylpyridinium chloride for $96 \mathrm{~h}$ duration. The $\mathrm{LC}_{50}$ values associated with $95 \%$ lower and upper confidence limits for the surfactant were determined statistically using Finney's Probit Analysis Method developed by EPA and were found to be $0.330(0.305-0.357) \mathrm{ppm}, 0.305(0.280-0.332) \mathrm{ppm}, 0.225(0.204-0.248) \mathrm{ppm}$ and $0.213(0.190-0.240)$ ppm at 24, 48, 72 and 96 hours exposure respectively. The results of regression analysis indicated that the mortality rate varied significantly $(\mathrm{p}<0.05)$ with the increasing concentrations of surfactant. In addition, the aquatic worm exhibited abnormal behavioral responses like hyperactivity, decreased clumping tendency, increased mucous secretion and wrinkling effect on increasing concentrations of toxicant and period of exposure. Thus, these findings can be used as a potential tool for creating awareness among people to limit the misuse of household products containing surfactants.
\end{abstract}

Keywords - Acute toxicity, Cetylpyridinium chloride, Tubifex tubifex, behavioral response

\section{INTRODUCTION}

Water is the most important component for the survivability of life. It is an essential constituent of all flora and fauna. But exorbitant discharge of household, domestic effluents, and detergents into the water bodies contaminate the water causing the death of non-target aquatic organisms. Surfactants, one of the crucialcomponents of household products, impose an adverse impact on the water bodies resulting in enhanced mortality of aquatic fauna [1]. One such extremely commercialized cationic surfactant is Cetylpyridinium chloride (CPC), a quaternary cationic ammonium compound, specifically utilized in mouthwash and toothpaste for obviation of tooth plaques and periodontal disease [2],[3],[4]. Additionally, it also removes reactive dyes, phenols, and different organic solutes from waste products or treated effluents [5],[6],[7].

Several studies were conducted relating to the oral intoxication of CPC to rats and mice [8],[9]. But studies regarding its hazardous impact to benthic aquatic organisms are scanty. In the present study, the benthic oligochaete worm, Tubifex tubifex was selected as a test organism because it is an important benthic bio indicator species, cosmopolitan in distribution, possess a high tolerance to a diverse array of environmental variables and additionally serves as a healthy food source of fishes specifically fresh water ornamental ones [10],[11],[12],[13],[14].

Thus the present investigation was conducted to determine the acute toxicity of CPC in terms of $\mathrm{LC}_{50}$ and behavioral responses as an indicator of chemical stress to Tubifex tubifex.

The paper is organized as follows, Section I contains the Introduction of the toxicant, CPC and its effect on aquatic ecosystem. Section II contains some related works regarding the toxicity of CPC. Section III contains the methodology employed to pursue the present study. Section IV describes the results and discussions associated with tables and graphical representations and Section $\mathrm{V}$ concludes the research work with future scopes.

\section{RELATED WORKS}

Rosen et al, (1965) "Dimethyl sulfoxide (DMSO) as a solvent in acute toxicity determinations" - evaluated the acute toxcity of CPC on both rats and mice in the presence of distilled water and dimethyl sulfoxide (DMSO) [8]. 
Nelson et al, (1946)“The toxicity of myristyl-gammapicolinium chloride" - determined the $\mathrm{LD}_{50}$ value of CPC in rats and the values are $250 \mathrm{mg} . / \mathrm{Kg}$. subcutaneously, 6 $\mathrm{mg} . / \mathrm{Kg}$. intraperitoneally, $30 \mathrm{mg} . / \mathrm{Kg}$. intravenously, and 200 $\mathrm{mg} . / \mathrm{Kg}$. Orally [9].

M.H. Li, (2012) "Survival, mobility, and membrane-bound enzyme activities of freshwater planarian, Dugesia japonica, exposed to synthetic and natural surfactants" - studied the acute toxicity and locomotary changes of fresh water planarian Dugesia japonica upon exposure to CPC [15].

\section{METHODOLOGY}

\section{Collection of the test organism}

The bio indicator species, Tubifex tubifex were collected from the local market of Burdwan, West Bengal, India and acclimatized in the laboratory for a period of $24 \mathrm{~h}$ in unclorinated pollution free water (temperature $26.5 \pm 0.2{ }^{\circ} \mathrm{C}, \mathrm{pH}$ $7.4 \pm 0.4$, free $\mathrm{CO}_{2} 16.4 \pm 0.7 \mathrm{mg} / \mathrm{l}$, dissolved oxygen $6.9 \pm$ $0.2 \mathrm{mg} / \mathrm{l}$, total alkalinity $187 \pm 7.3 \mathrm{mg} / \mathrm{l}$ as $\mathrm{CaCO}_{3}$, hardness $118 \pm 4.9 \mathrm{mg} / \mathrm{l}$ as $\mathrm{CaCO}_{3}$ ). Then healthy organisms with a mean length of $11.6 \pm 0.4 \mathrm{~mm}$ were transferred to the experimental system.

\section{Test chemical used}

Technical grade of CPC was procured from SRL and used as a test chemical. Its stock solution (1\%) and dilutions were made following the APHA method (2012) [16].

\section{Acute toxicity bioassay}

To determine the $\mathrm{LC}_{50}$ value of $\mathrm{CPC}, 96$ hours static renewal acute toxicity test was conducted in a controlled laboratory condition by exposing Tubifex tubifex $(\mathrm{n}=10)$ to different concentrations of CPC. Each experiment was conducted in triplicates. Initially a range finding test was piloted to find out the range of the concentrations where mortality occurs. Thereafter a definitive test was conducted byexposing the worms to different concentrations of surfactant i.e. 0.1, 0.125, $0.15,0.175,0.2,0.225,0.25,0.275,0.3,0.325,0.35,0.375$, $0.4,0.425 \mathrm{mg} / \mathrm{l}$ along with a control. Based on the toxicant dose and percent mortality at $24,48,72$ ad $96 \mathrm{hrs}$, the $\mathrm{LC}_{50}$ values along with $95 \%$ confidence limits were determined by using Finney's probit analysis method [17]. The behavioural responses of the worm were observed and recorded at different exposure periods by employing semi quantitative scoring method [18].The toxicological end points like LOEC (Lowest Observed Effect Concentration), NOEC (No Observed Effect Concentration) at 96h were determined based on the acute toxicity data. MATC (Maximum Acceptable Toxicant Concentration) was calculated by multiplying 96h LC $\mathrm{LC}_{50}$ value with Application Factor 0.1 [19].

\section{Determination of Safe permissible limit of the toxicant}

The safe level of CPC was calculated by using Application Factors based on Edwards and Brown [20], Burdick [21], Sprague [22] Water Quality Criteria (CWQC) [23], National
Academy of Science/National Academy of Engineering (NAS/NAE) [24], International joint commission [25], and Canadian council of Resources and Environmental Ministry (CCREM) (IJC) [26].

\section{Statistical Analysis}

The statistical analysis was carried out by employing Graphpad prism 7.0. The linear regression curves were drawn by employing MS Excel 2013.

\section{RESULTS AND DISCUSSION}

Acute toxicity and determination of 96 hrs. $\mathrm{LC}_{50}$ No mortality was observed in controlworms as well as worms treated with $0.1 \mathrm{mg} / \mathrm{lit}$ of toxicant throughout $96 \mathrm{~h}$. However, with the further increment of the concentrations of the toxicant and the exposure period, the mortality rate increased (Table 1). This observation designated that mortality is dose and time dependent. The $\mathrm{LC}_{10}$ to $\mathrm{LC}_{90}$ values of CPC observed in the 24, 48, 72 and 96h exposure period were represented in Table 2. The 24, 48, 72 and 96h $\mathrm{LC}_{50}$ values, 95\% confidence limits, and correlation coefficients of CPC at different exposure periods for Tubifex tubifex are summarized in Table 3 which indicates an existence of a strong positive correlation between the percentage mortality and toxicant concentration. The regression plots of probit mortality against $\log _{10}$ concentrations of CPC for 24, 48, 72 and $96 \mathrm{~h}$. have been depicted in Figure 1. The NOEC, LOEC and MATC values at 96h were determined and compared with the subsequent $\mathrm{LC}_{50}$ value which is depicted in Figure 2. The calculated values of LOEC, NOEC and MATC are 0.125, $0.1 \mathrm{mg} / \mathrm{l}$ and 0.0213 $\mathrm{mg} / \mathrm{l}$ respectively.

\section{Behavioural changes in Tubifex tubifex due to acute toxicity}

Upon addition of CPC at different exposure periods, the Tubifex tubifex exhibited dose and duration dependent irregular behavioural responses which are represented in Table 4. The control worms exhibited normal behavioural attributes throughout the exposure period. But a decline in the clumping propensity and increment in hyperactivity, wrinkling effect, and mucous secretion of the exposed worms were observed with increasing concentrations of toxicant and exposure times.

\section{Safe concentrations}

The safe permissible limits of CPC calculated for the oligochaete worm Tubifex tubifex are represented in Table 5 and is found to be within the range of $0.0000213-0.01065$ ppm.

\section{Discussion}

In the present investigation, Tubifex tubifex exhibited variations in mortality rate with the incrementing surfactant concentrations and exposure period. In the present study, the 
96h $\mathrm{LC}_{50}$ value of CPC to Tubifex tubifex is estimated to be $0.213 \mathrm{mg} / \mathrm{l}$ which is much higher than the other aquatic animals as reported to be $0.04 \mathrm{mg} / \mathrm{l}$ in case of fresh water planarian (Dugesia japonica) [15] and $0.01 \mathrm{mg} / \mathrm{l}$ in case of common carp (Cyprinus carpio) according to Reagentworld Material Safety Data Sheet.

According to the value of $96 \mathrm{~h} \mathrm{LC}_{50}$ of $\mathrm{CPC}$, it is regarded as highly toxic to aquatic organisms. However its toxicity may vary depending on temperature, $\mathrm{pH}$, alkalinity and hardness of the water.

The behavioural changes are specifically related to intricate physiological responses and have often been utilized as a sensitive stress designator [27]. In our present investigation, the vicissitudes of clumping propensity, hyperactive movement, incremented wrinkling effect and enhanced mucous discharge of Tubifex tubifex upon exposure to CPC suggest that the tubificid worms have been subjected to chemical stress when exposed to surfactant and can be considered as a marker of aquatic contamination. Parallel trends in behavioural changes were observed when similar type of aquatic oligochaete worms Branchiura sowerbyi were exposed to pesticide like alpha-cypermethrin and heavy metal like Cadmium [28],[29].

The $96 \mathrm{~h} \mathrm{LC}_{50}$ of CPC to Tubifex tubifex is also useful in determining the range of the safe permissible limit of the toxicant $(0.0000213-0.01065 \mathrm{ppm})$. If the amount of the surfactant entering the aquatic water body exceeds the range of its safe permissible limit, it might impose detrimental effect on the survivability of this economically important bioindicator species as well as fish population.

\section{CONCLUSION AND FUTURE SCOPE}

The present investigation exhibited that the mortality rate of Tubifex tubifex upon addition of CPC is dose and duration dependent. It is exposed from the work that CPC is prodigiously toxic to aquatic bio indicator species, Tubifex tubifex based on its $\mathrm{LC}_{50}$ values which were estimated to be $0.330,0.315,0.225$ and $0.213 \mathrm{mg} / \mathrm{l}$ for $24,48,72$ and $96 \mathrm{hrs}$. exposure period respectively. Moreover, the study also establishes the significance of behavioural parameters as a designator of chemical stress in case of benthic aquatic organisms. Thus the present findings regarding the toxicity of CPC to Tubifex tubifex may be used as a potential tool for creating awareness among people to restrict the exorbitant utilization of surfactants and preventive measures should be undertaken before its disposal to the aquatic environment to eschew any eco-toxicological hazards. However further studies are required regarding the changes in status of antioxidant enzymes in case of Tubifex tubifex upon addition of this surfactant.

\section{CONFLICT OF INTEREST}

The authors have no conflict of interest.

\section{ACKNOWLEDGMENT}

The authors are thankful to the Head, Department of Zoology, The University of Burdwan for providing infrastructural facilities and DST PURSE PHASE II fellowship for providing financial support to carry out the work.

Table 1: Correlation between CPC concentrations \& mortality rate of Tubifex tubifex at different hours of exposure

\begin{tabular}{|c|c|c|c|c|c|c|c|c|c|c|c|}
\hline $\begin{array}{c}\text { CPC } \\
\text { Conc. } \\
\text { (mg/lit) }\end{array}$ & $\begin{array}{c}\text { CPC } \\
\text { Conc. } \\
(\mu \mathrm{g} / \text { lit })\end{array}$ & $\begin{array}{c}\text { Log } \\
\text { Conc. } \\
\text { ( } \mu \mathrm{g} / \mathrm{git})\end{array}$ & $\begin{array}{c}\text { No of } \\
\text { worms } \\
\text { exposed }\end{array}$ & \multicolumn{2}{|c|}{24 hours } & \multicolumn{2}{|c|}{48 hours } & \multicolumn{2}{|c|}{72 hours } & \multicolumn{2}{|c|}{96 hours } \\
\hline 0.125 & 125 & 2.10 & 10 & 0 & - & 0 & - & 0 & - & 10 & 3.72 \\
\hline 0.15 & 150 & 2.18 & 10 & 0 & - & 0 & - & 10 & 3.72 & 20 & 4.16 \\
\hline 0.175 & 175 & 2.24 & 10 & 0 & - & 0 & - & 20 & 4.16 & 30 & 4.48 \\
\hline 0.25 & 250 & 2.40 & 10 & 10 & 3.72 & 20 & 4.16 & 60 & 5.25 & 60 & 5.25 \\
\hline 0.275 & 275 & 2.44 & 10 & 20 & 4.16 & 40 & 4.75 & 70 & 5.52 & 70 & 5.52 \\
\hline 0.3 & 300 & 2.48 & 10 & 40 & 4.75 & 50 & 5.00 & 80 & 5.84 & 90 & 6.28 \\
\hline 0.325 & 325 & 2.51 & 10 & 50 & 5.00 & 50 & 5.00 & 90 & 6.28 & 100 & - \\
\hline 0.35 & 350 & 2.54 & 10 & 50 & 5.00 & 70 & 5.52 & 100 & - & 100 & - \\
\hline
\end{tabular}


Table 2: Acute toxicity of CPC to Tubifex tubifex at different exposure periods

\begin{tabular}{|l|l|l|l|l|}
\hline \multirow{2}{*}{ Critical Level } & \multicolumn{4}{|l|}{ Lethal concentration value at different exposure period (ppm) } \\
\cline { 2 - 5 } & $\mathbf{2 4 h}$ & $\mathbf{4 8 h}$ & $\mathbf{7 2 h}$ & $\mathbf{9 6 h}$ \\
\hline $\mathrm{LC}_{10}$ & 0.235 & 0.211 & 0.149 & 0.129 \\
\hline $\mathrm{LC}_{20}$ & 0.264 & 0.239 & 0.172 & 0.153 \\
\hline $\mathrm{LC}_{30}$ & 0.287 & 0.262 & 0.190 & 0.173 \\
\hline $\mathrm{LC}_{40}$ & 0.309 & 0.283 & 0.208 & 0.193 \\
\hline $\mathbf{L C}_{\mathbf{5 0}}$ & $\mathbf{0 . 3 3 0}$ & $\mathbf{0 . 3 0 5}$ & $\mathbf{0 . 2 2 5}$ & $\mathbf{0 . 2 1 3}$ \\
\hline $\mathrm{LC}_{60}$ & 0.353 & 0.328 & 0.244 & 0.236 \\
\hline $\mathrm{LC}_{70}$ & 0.379 & 0.354 & 0.266 & 0.262 \\
\hline $\mathrm{LC}_{80}$ & 0.412 & 0.388 & 0.295 & 0.297 \\
\hline $\mathrm{LC}_{90}$ & 0.463 & 0.441 & 0.339 & 0.354 \\
\hline
\end{tabular}

Table 3: The $\mathrm{LC}_{50}$ values, $95 \%$ confidence limits, and Correlation Coefficients of CPC to Tubifex tubifex at different exposure periods $(24,48,72$ and $96 \mathrm{~h})$

\begin{tabular}{|l|l|l|l|l|}
\hline Exposure period & \multirow{2}{\text{LC}}{$\begin{array}{c}\mathbf{5 0} \\
\text { value } \pm \text { SE }\end{array}$} & \multicolumn{2}{|c|}{$\mathbf{9 5 \%}$ confidence limit } & $\begin{array}{c}\text { Correlation coefficient } \\
(\mathbf{p p m})\end{array}$ \\
\cline { 3 - 4 } & & \multicolumn{1}{|c|}{ Lower } & Upper & \\
\hline $24 \mathrm{~h}$ & $0.330 \pm 0.017$ & 0.305 & 0.357 & $0.979^{*}$ \\
\hline $48 \mathrm{~h}$ & $0.305 \pm 0.019$ & 0.280 & 0.332 & $0.978^{*}$ \\
\hline $72 \mathrm{~h}$ & $0.225 \pm 0.022$ & 0.204 & 0.248 & $0.994^{*}$ \\
\hline $96 \mathrm{~h}$ & $0.213 \pm 0.026$ & 0.190 & 0.240 & $0.973^{*}$ \\
\hline
\end{tabular}

*Values indicate statistical significance at 0.01 levels $(\mathrm{P}<0.01)$
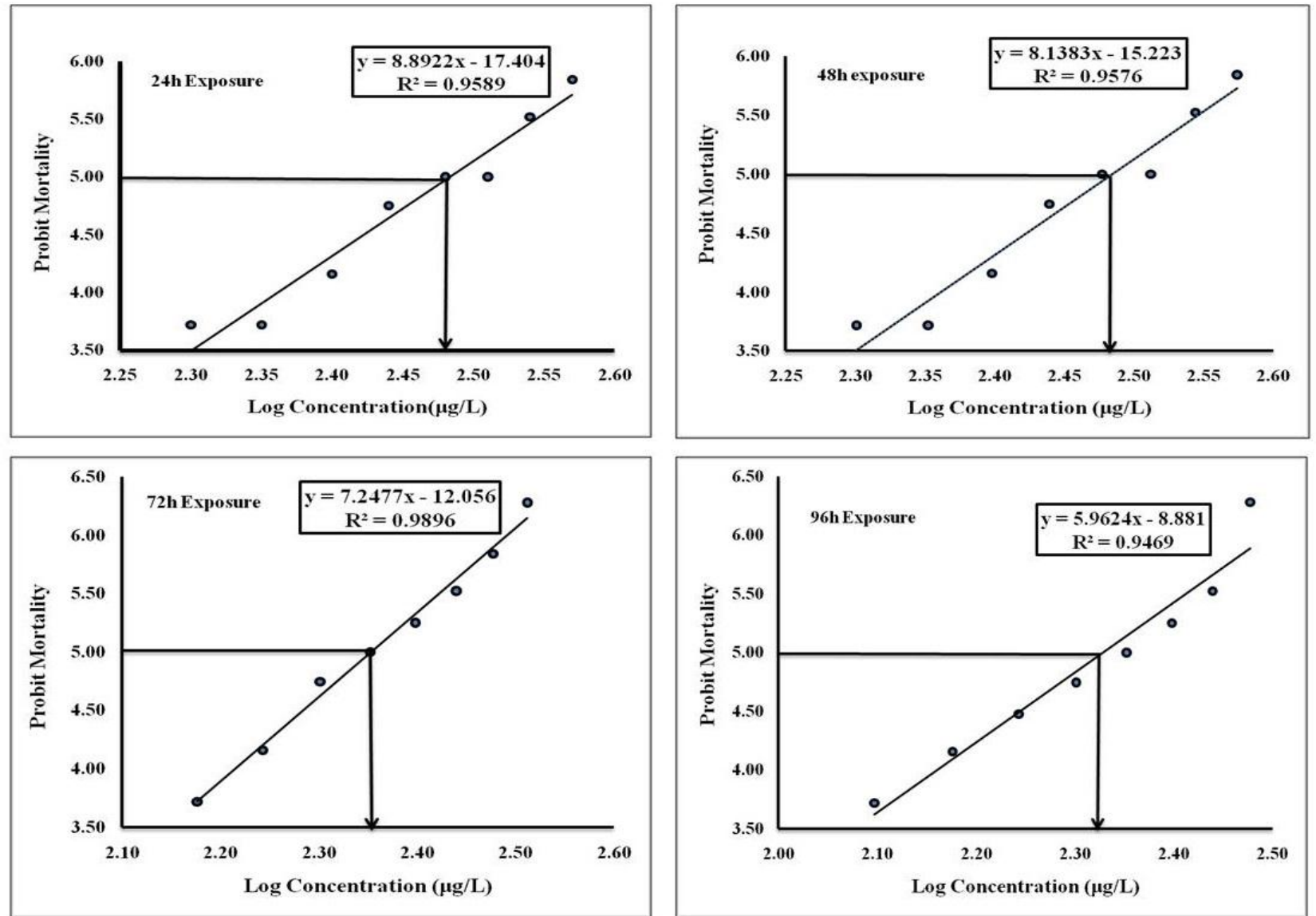

Fig 1: Regression plot between Log concentration and probit mortality of CPC to Tubifex tubifex at different exposure periods $(p<0.05)$. 
0.25
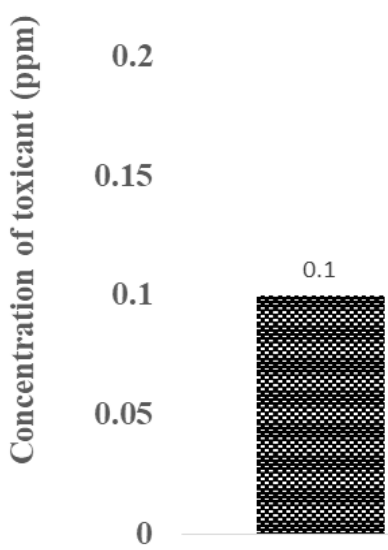

NOEC

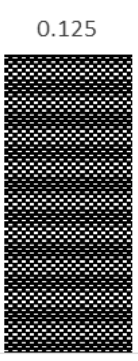

LOEC

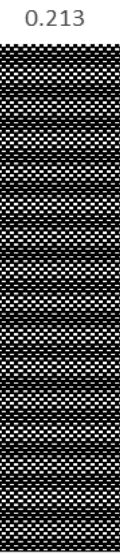

LC50

Fig 2: Comparison between NOEC, LOEC, MATC and $\mathrm{LC}_{50}$ value of the toxicant at 96h exposure

Table 4: Impact of CPC on behavioural responses of Tubifex tubifex (HM: Hyperactive movement; CT: clumping tendency; MS: mucus secretion; WE: wrinkling effect; -: none; +: mild; ++: moderate; +++: strong) at different concentrations in different exposure period

\begin{tabular}{|c|c|c|c|c|c|c|c|c|c|c|c|c|c|c|}
\hline \multicolumn{15}{|c|}{ Behavioral Responses of Tubifex tubifexupon addition of CPC } \\
\hline \multirow{2}{*}{$\begin{array}{l}\text { Time of } \\
\text { exposure } \\
\text { (hrs.) }\end{array}$} & \multirow{2}{*}{$\begin{array}{c}\text { Behavioural } \\
\text { parameters }\end{array}$} & \multicolumn{13}{|c|}{ Dose of CPC (ppm) } \\
\hline & & 0.125 & 0.15 & 0.175 & 0.2 & 0.225 & 0.250 & 0.275 & 0.3 & 0.325 & 0.350 & 0.375 & 0.4 & 0.425 \\
\hline \multirow{3}{*}{24} & CT & +++ & +++ & +++ & +++ & +++ & ++ & ++ & ++ & ++ & + & + & + & + \\
\hline & MS & - & - & - & - & - & + & + & ++ & ++ & ++ & +++ & +++ & +++ \\
\hline & WE & - & - & - & - & - & - & + & + & ++ & ++ & ++ & +++ & +++ \\
\hline \multirow{3}{*}{48} & CT & +++ & +++ & ++ & ++ & ++ & ++ & ++ & + & + & + & + & - & - \\
\hline & MS & - & - & - & - & + & + & ++ & ++ & +++ & +++ & +++ & +++ & +++ \\
\hline & WE & - & - & - & - & + & + & ++ & ++ & ++ & ++ & +++ & +++ & +++ \\
\hline \multirow[t]{2}{*}{72} & HM & - & - & - & + & + & + & + & + & + & + & ++ & ++ & ++ \\
\hline & CT & ++ & ++ & ++ & ++ & + & + & + & + & - & - & - & - & - \\
\hline \multirow{3}{*}{96} & CT & ++ & ++ & ++ & ++ & + & + & + & + & + & + & + & + & + \\
\hline & MS & - & - & - & + & + & + & + & + & ++ & ++ & ++ & ++ & ++ \\
\hline & WE & - & - & - & + & + & + & + & ++ & ++ & ++ & +++ & +++ & +++ \\
\hline
\end{tabular}

Table 5: Safe permissible limit of CPC to oligochaete worm Tubifex tubifex

\begin{tabular}{|c|c|c|c|c|}
\hline Surfactant & 96 h LC $\mathbf{L C}_{\mathbf{5 0}}$ (ppm) & Method & Application Factor (AF) & Safe Level(mg/l) \\
\hline \multirow{4}{*}{$\mathrm{N}$} & & Edwards and Brown (1966) & 0.4 & 0.0852 \\
\cline { 3 - 5 } & \multirow{4}{*}{0.213} & Burdick (1967) & 0.1 & 0.0213 \\
\cline { 3 - 5 } & & Sprague(1971) & 0.1 & 0.0213 \\
\cline { 3 - 5 } & & CWQC (1972) & 0.01 & 0.00213 \\
\cline { 3 - 5 } & & NAS/NAF (1973) & $0.1-0.0001$ & $0.0213-0.0000213$ \\
\cline { 3 - 5 } & & IJC (1977) & $5 \%$ of 96h LC50 & 0.01065 \\
\cline { 3 - 5 } & & CCREM (1991) & 0.05 & 0.01065 \\
\hline
\end{tabular}




\section{REFERENCES}

[1]. C.L. Yuan, Z.Z. Xu, M.X. Fan, H.Y. Liu, Y.H. Xie, T. Zhu, "Study on characteristics and harm of surfactants", Journal of chemical and pharmaceutical research, Vol.6, Issue.7, pp.2233-2237, 2014.

[2]. G. McDonnell, A.D. Russell, "Antiseptics and disinfectants: activity, action, and resistance", Clinical microbiology reviews, Vol.14, Issue.1, pp.227, 2001.

[3]. M. Pardini, F. Varaine, E. Iona, E. Arzumanian, F. Checchi, M.R. Oggioni, G. Orefici, L. Fattorini, "Cetyl-pyridinium chloride is useful for isolation of Mycobacterium tuberculosis from sputa subjected to long-term storage", Journal of clinical microbiology, Vol.43, Issue.1, pp.442-444, 2005.

[4]. X. Costa, E. Laguna, D. Herrera, J. Serrano, B. Alonso, M. Sanz, "Efficacy of a new mouth rinse formulation based on $0.07 \%$ cetylpyridinium chloride in the control of plaque and gingivitis: a 6- month randomized clinical trial", Journal of clinical periodontology, Vol.40, Issue.11, pp.1007-1015, 2013.

[5]. A.L. Ahmad, S.W. Puasa, "Reactive dyes decolourization from an aqueous solution by combined coagulation/micellarenhanced ultrafiltration process", Chemical Engineering Journal, Vol.132, Issue.1-3, pp.257-265, 2007.

[6]. F. Luo, G.M. Zeng, J.H. Huang, C. Zhang, Y.Y. Fang, Y.H. $\mathrm{Qu}, \mathrm{X}$. Li, D. Lin, C.F. Zhou, "Effect of groups difference in surfactant on solubilization of aqueous phenol using MEUF", Journal of hazardous materials, Vol.173, Issue.1-3, pp.455461, 2010

[7]. S. Buffet-Bataillon, P. Tattevin, M. Bonnaure-Mallet, A. Jolivet-Gougeon. "Emergence of resistance to antibacterial agents: the role of quaternary ammonium compounds-a critical review", International journal of antimicrobial agents, Vol.39, Issue.5. pp.381-389, 2012.

[8]. H. Rosen, A. Blumenthal, R. Panasevich, J. McCallum, "Dimethyl sulfoxide (DMSO) as a solvent in acute toxicity determinations", Proceedings of the Society for Experimental Biology and Medicine, Vol.120, Issue.2, pp.511-514, 1965.

[9]. J.W. Nelson, S.C. Lyster, "The toxicity of myristyl-gammapicolinium chloride", Journal of the American Pharmaceutical Association, Vol.35, Issue.3, pp.89-94, 1946.

[10].P.M. Chapman, "Utility and relevance of aquatic oligochaetes in ecological risk assessment", In Aquatic Oligochaete Biology VIII, Springer, Dordrecht, pp.149-169, 2001.

[11].R.J. Aston, "Tubificids and water quality: a review", Environmental Pollution (1970), Vol.5, Issue.1, pp.1-10, 1973.

[12].J.L. Kaster, "The reproductive biology of Tubifex tubifex Muller (Annelida: Tubificidae)", American Midland Naturalist, Vol.104, No.2, pp.364-366, 1980.

[13].A.S. Chong, R. Hashim, A.B. Ali, "Dietary protein requirements for discus (Symphysodon spp.)", Aquaculture Nutrition, Vol.6, Issue.4, pp.275-278, 2000.
[14].C.S. Tamaru, H. Ako, R. Paguirigan, "Essential fatty acid profiles of maturation feeds used in freshwater ornamental fish culture", Hydrobiologia, Vol.358, Issue.1-3, pp.265-268, 1997.

[15].M.H. Li, "Survival, mobility, and membrane- bound enzyme activities of freshwater planarian, Dugesia japonica, exposed to synthetic and natural surfactants", Environmental toxicology and chemistry, Vol.31, Issue.4, pp.843-850, 2012.

[16].APHA, "Standard Methods for the Examination of Water and Wastewater 20th Edition", United Book Press, Maryland, United States, 1998.

[17].D.J. Finney, "Probit Analysis", Cambridge University Press, Cambridge, England, pp.333, 1971.

[18].C. Sarkar, S. Bej, N.C. Saha, "A study on the acute toxicity of Triazophos to Branchiurasowerbyi (Beddard, 1982) and their behavioural changes", International Journal of Scientific Research, Vol.5, Issue.5, 2016.

[19].S. Gheorghe, C. Stoica, G.G. Vasile, M. Nita-Lazar, E, Stanescu, I.E. Lucaciu,"Metals Toxic Effects in Aquatic Ecosystems: Modulators of Water Quality", Water Quality, Hlanganani Tutu, IntechOpen, 2017.

[20].R.W. Edwards, V.M. Brown, "Pollution and fisheries: a progress report", Water Pollution Control, Vol.66, pp.63-78, 1967.

[21].G.E. Burdick, "Use of bioassays in determining levels of toxic wastes harmful to aquatic organisms", American Fisheries Society Special Publication, Vol.4, pp.7-12, 1967.

[22].J.B. Sprague, "Measurement of pollutant toxicity to fish-III: Sublethal effects and "safe" concentrations", Water Research, Vol. 5, Issue.6, pp.245-266, 1971.

[23].Committee on Water Quality Criteria, "A report of the committee on water quality and research series", US Environmental Protection Agency Report; Lincinnati, OH, USA, 1972.

[24].National Academy of Science/National Academy of Engineering (NAS/NAE), "Water quality criteria, EPA -R3033”, US Government Printing Office: Washington DC, USA, 1973.

[25].International Joint Commission (IJC), "New and Revised Great Lakes Water Quality Objectives. Great lake basin, Windsor", IJC: Ottawa, ON, Canada, 1977.

[26]. Canadian Council of Resources and Environmental Ministry, "Canadian Water Quality Guidelines", Canadian Council of Resources and Environmental Ministry, Inland waters Directorate, Environment Canada, Ottawa, Canada, 1991.

[27].E.E. Little, S.E. Finger, "Swimming behavior as an indicator of sublethal toxicity in fish", Environmental Toxicology and Chemistry: An International Journal, Vol.9, Issue.1, pp.13-19, 1990.

[28].S. Bej, D. Mukherjee, N.C. Saha, "Acute toxicity of alphacypermethrin to oligochaete worm, Branchiura sowerbyi (Beddard, 1982) along with their behavioural responses", International Journal of Scientific Research, Vol.4, Issue.12, 2015 . 
[29]. K Dhara, D Mukherjee, NC Saha, “Acute Toxicity of Cadmium to Benthic Oligochaete Worm, Branchiura sowerbyi Beddard, 1982 and Juvenile Catfish, Clarias batrachus Linnaeus, 1758 ", Proceedings of the Zoological Society, Springer, India, Vol.68, No.2, pp.116-119, 2015.

\section{AUTHORS PROFILE}

Mr.Ritwick Bhattacharya pursued his M.Sc. degree from The University of Burdwan in the year 2014. He had qualified GATE and WBSET (2019) and currently working as a state funded fellow in Fishery and Ecotoxicology Research Laboratory, Dept. of Zoology, The University of Burdwan, under

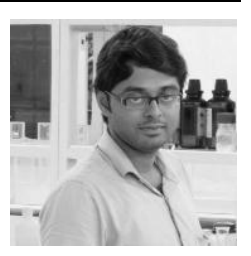
the supervision of Prof.Nimai Chandra Saha, Vice Chancellor, The University of Burdwan.He is working on the field of aquatic toxicology and ecotoxicology.(Toxicological effects of surfactants on fish and their bioremediation).

Mr.Arnab Chatterjee pursued his M.Sc. degree from The University of Burdwan in the year 2016. He had qualified CSIR-UGC NET JRF (Dec, 2016), LS (Dec, 2017) and GATE (2017). He is currently working as a UGC-JRF in Fishery and Ecotoxicology Research Laboratory, Dept. of Zoology, The University

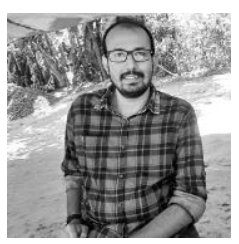
of Burdwan, under the supervision of Prof.Nimai Chandra Saha, Vice Chancellor, The University of Burdwan. He is working on the field of aquatic toxicology (effects of pesticides/heavy metals/surfactant on fish and their bioremediation).

Prof.Nimai Chandra Saha is currently working as Vice Chancellor, The University of Burdwan. He had pursued his Ph.D. from Kalyani University. He has more than 30 years of teaching (both UG and PG) and research experience. He has published more than 70

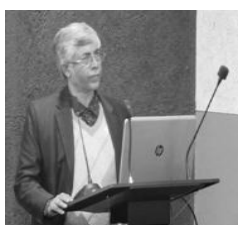
research and review articles in reputed national and international journals. $\mathrm{He}$ is working in the field of fishery science, aquatic toxicology, ecology \& environment and fish breeding. 